\title{
Changing Thoughts About Mineral Deposits: The 5th to 28th IGC
}

\section{by Brian J. Skinner}

\begin{abstract}
A century ago North American geologists showed little interest in the genesis of ore deposits, but by the time of the 1933 IGC in Washington there was a major emphasis on magmatic hydrothermalism, led by Waldemar Lindgren. This review traces the development of thinking on ore deposits to the contemporary focus on mineral deposit models.
\end{abstract}

\section{The Perspective in 1891}

When the 5th International Geological Congress met in Washington, D.C. in 1891, the study of mineral deposits seemed an established and secure speciality within geology. In the U.S.A. and adjacent Canada, those who specialized in the topic were largely concerned with practical questions of testing and mining the rich ores that prospectors had discovered. Papers of that period tended to be objective and directed more toward helping the miner with his problems, than to be scientifically oriented and concerned with esoteric issues such as the genesis of ore bodies. The time of the 5 th IGC can be seen in retrospect to be a time of change.

There were, to be sure, some North American geologists who had already turned their attentions to problems of ore genesis. These included S.F. Emmons, one of the two Secretaries General of the 5th IGC, and other well-known authorities, such as Clarence King (first Director of the U.S. Geological Survey), W.H. Weed and C.R. Van Hise. Despite the distinction of these men and a few of their contemporaries, the great body of scientific opinion concerning classification schemes and the genesis of mineral deposits had, up to 1891, arisen from the work of European geologists. The issues that challenged them most were the classification and genesis of the metallic ores we loosely lump together under the name hydrothermal.

There had been an almost century-long debate on the genesis of metallic ores in Europe. The roots of the debate actually went back much farther than the 19th century, but the real consequences and significance of the opposing viewpoints were first examined in the 1800 s. One school of thought derived its ideas from the 16 th century suggestions of Agricola, who held that metallic mineral deposits had formed through lateral secretion. In this viewpoint, veins and other mineralized bodies were the offspring of the enclosed rocks by circulating groundwaters, and then deposited by the solutions in fractures.

A second school of thought derived its ideas from the 17th century opinion of Descartes who reasoned that the Earth is a cooling star, that it is still outgassing, and that metallic mineral deposits form from the outgassing vapors. The vapors, or fluids, were considered to be aqueous and to have risen from unseen depths in the crust, possibly even from that portion of the Earth we now call the mantle. Mineralized veins, in this perception, were introduced bodies that were not necessarily related genetically to the enclosing host rocks. There were, of course, many shades of opinion at both ends of the spectrum and at every point in between.

American geologists do not seem to have been very concerned with the subtleties of the theories concerning ore genesis. The name of the man who is credited with convincing them to be concerned appears in the lists of the General Membership of the 5th IGC. He was the Czech geologist Frantisek Pošepný. I cannot find any record of Pošepný having delivered a paper at the Congress, nor do I know whether or not he participated in any of the wonderful field trips that occupied the summer of 1891.

Pošepný was already well known to some American geologists in 1891, and his thinking had clearly been admired by some of the continent's influential scientists. Two years later, in 1893, Pošepný was invited to present his ideas before the annual meeting of the American Institute of Mining Engineers (AIME) in Chicago. He delivered an epochal address, and his words appeared in print in an AIME book published in 1895, and revised in a second edition in 1902. The latter edition contains a report of the discussions at the 1893 meeting together with written commentaries by Van Hise, Weed, Emmons, J.F. Kemp, J.L. Vogt, W.P. Blake, T.A. Rickard, and, most importantly, Waldemar Lindgren. It is this second edition to which most reference is made today. As Gabriel and Pouba (1986) point out, the time and the place were just right for Pošepny's ideas.

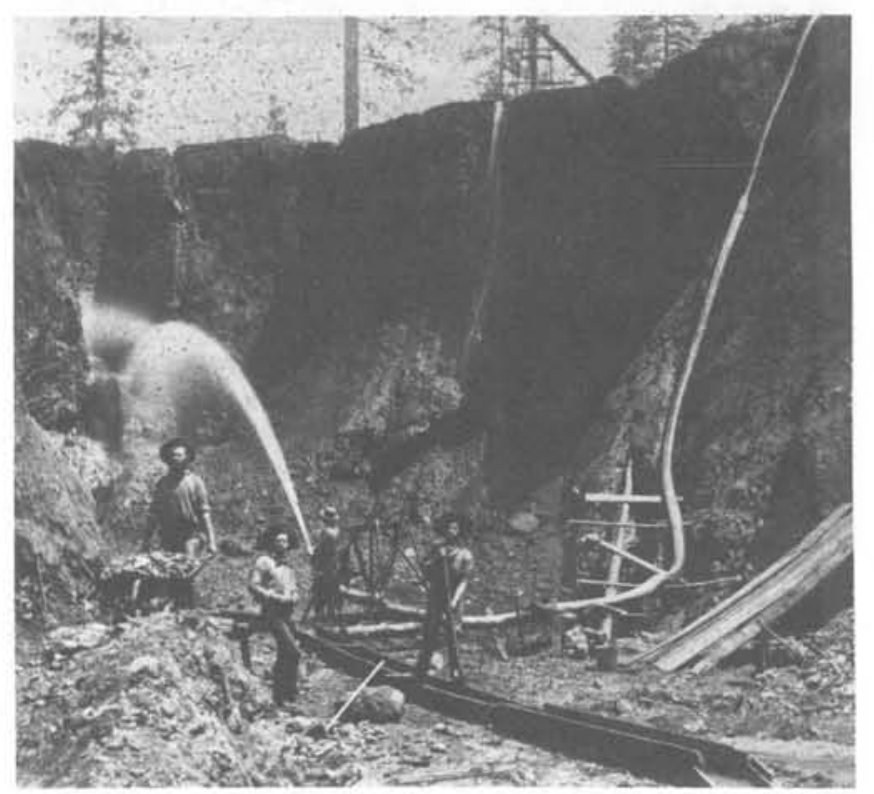

Pigure 1: Hydraulic mining for gold in California during the 1870s. The exact date of the photograph (which shows obvious signs of decay) is uncertain. 


\section{Mineral Discoveries Set the Pace}

The time was right because the geological exploration of the American west was proceeding rapidly. Efficient modes of transportation had become available, and reliable means of communications had been installed. These changes happened at the same time as the ebbing of a long period of hostility and lawlessness on the frontier. Prospecting and mine development were made easier, and this in turn broadened geological investigations. In both the United States and Canada, a seemingly endless string of rich mineral deposits was discovered (Fig. 1). Some of these, such as at Sudbury, Leadville, Comstock, and the Mother Lode, seemed to be unlike anything ever seen before.

The small community of American geologists who had a chance to visit, study, and think about all the geological riches discovered in the west were exceptionally fortunate. Emmons, Weed, Tarr, and Lindgren had observational riches aplenty to ponder as they and their colleagues thought through the consequences of Pošepnýt's ideas.

Pošepný argued that there were very good reasons to study the genesis of mineral deposits. The more one knows about how a deposit is formed, the better one is able to assess the problems that lie ahead for the miner, and the better is one's chance of finding new ore and new ore bodies (Figs. 2, 3). His words made good sense in 1893 as they do, indeed, today. Pošepný argued further that the genesis of each deposit should be studied as an entity, not as part of a larger class. Many would not agree completely with that sentiment today, but certainly it helped Pošepný keep an open

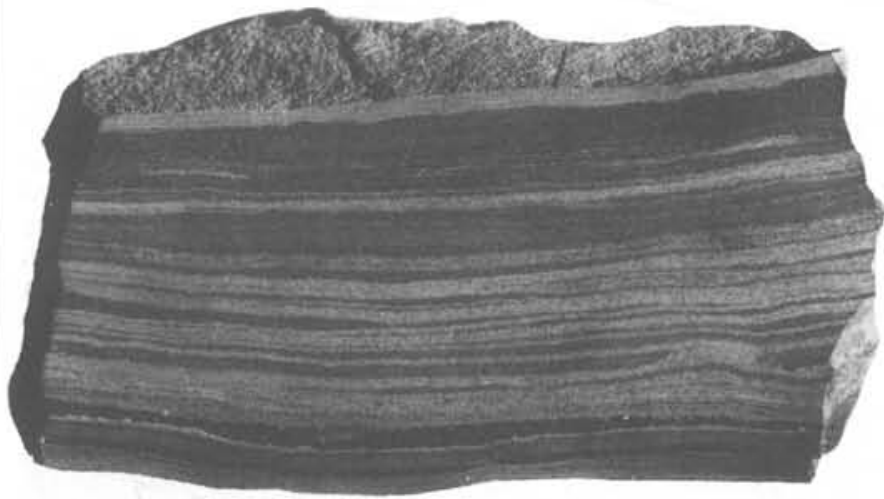

Figure 2: Banded iron formations were the protore for the rich, secondary iron ores being mined in the Mesabi Range, Minnesota when Pošepný visited the U.S.A. The fine layering of chert (light) and iron minerals (dark) was recognized to be sedimentary in origin, but then, as now, the nature of the primary sediments themselves was conjectural. Geologists played an important role in the exploitation of the secondary ores by elucidating the way leaching controlled their development. The specimen is from the Mesabi Range and is $12 \mathrm{~cm}$ wide.

mind in the debate of mineral veins formed through ascending versus laterally secreting ore fluids. He contended that most metallic ores somehow were derived from fluids that rose up and introduced them into their host rocks. The composition and properties of the fluid probably varied very little. The kind of deposit that was formed, he inferred, had more to do with the depth environment at which ore deposition occurred than with most other factors.

\section{Waldemar Lindgren}

Pošepnýs idea helped people to clear up their own thoughts. And in the mind of one young geologist, Pošepný's thinking catalyzed the development of some extraordinarily
Table 1: Lindgren's 1913 classification of ores formed through "introduction of substances foreign to the rock."

\section{A Origin independent of igneous activity}

By circulating atmosphere waters at moderate or slight depth. Temperature, to $100^{\circ} \mathrm{C}$. Pressure, moderate.

B Origin dependent upon the eruption of igneous rocks

a) By hot ascending waters of uncertain origin, but charged with igneous emanations.

1 Deposition and concentration at slight depth. Temperature, $50^{\circ} \pm$ to $150^{\circ} \mathrm{C} \pm$. Pressure, moderate.

2 Deposition and concentration at intermediate depths. Temperature, $150^{\circ} \pm$ to $300^{\circ} \mathrm{C} \pm$. Pressure, high.

3 Deposition and concentration at great depth or at high temperature and pressure. Temperature, $300^{\circ} \pm$ to $500^{\circ} \mathrm{C} \pm$. Pressure, very high.

b) By direct igneous emanations.

1 From intrusive bodies. Contact metamorphic deposits and allied veins; pegmatites. Temperature, probably $300^{\circ} \pm$ to $800^{\circ} \mathrm{C} \pm$. Pressure, very high.

2 From effusive bodies. Sublimates and fumaroles. Temperature, $400^{\circ} \mathrm{C} \pm$. Pressure, atmospheric to moderate.

influential ideas. That young man was Waldemar Lindgren, an immigrant from Sweden who became a devoted American. Lindgren grew to become the most influential economic geologist of his age, and in due course he was appointed President of the 16 th session when the IGC met in the U.S.A. for a second time in 1933.

Lindgren was a firm believer in the idea that an understanding of ore genesis, and a classification scheme based on ore characteristics go hand in hand. To that end he codified the concept of depth-temperature zones for the deposition of many kinds of ore bodies. Some of the terms he developed for specific classes of ores - hypothermal, mesothermal, epithermal - remain in use today as descriptive terms for styles of mineralization, even though we now realize that pressure effects due to depth do not play the controlling genetic role Lindgren thought they did. Nor, indeed, do we still consider that the ascending of primary mineralizing fluids can give rise to some of the classes of ore deposits that Lindgren considered to have had such an origin.

Lindgren developed his prescient ideas in a long series of papers, most of them published while he was an employee of the USGS. He visited and studied an enormous number of ore deposits (e.g. Lindgren, 1900). He read voraciously, and he must have been a very convincing teacher. In 1913 he published the first edition of his text Mineral Deposits, which was to become one of the most influential geological textbooks ever written. Through four editions and numerous revisions, the last in 1933, just in time for delegates at the 16 th Congress to purchase a copy, Lindgren's volume encapsulated the thinking of the majority of North American economic geologists of the time.

\section{Magmatic Hydrothermalism}

Central to Lindgren's thinking was the perception that the class of ores formed, as he wrote, as a result of "concentration effected by introduction of substances foreign to the rock," could be divided into two groups: "those independent of igneous activity and those dependent on the eruption of 


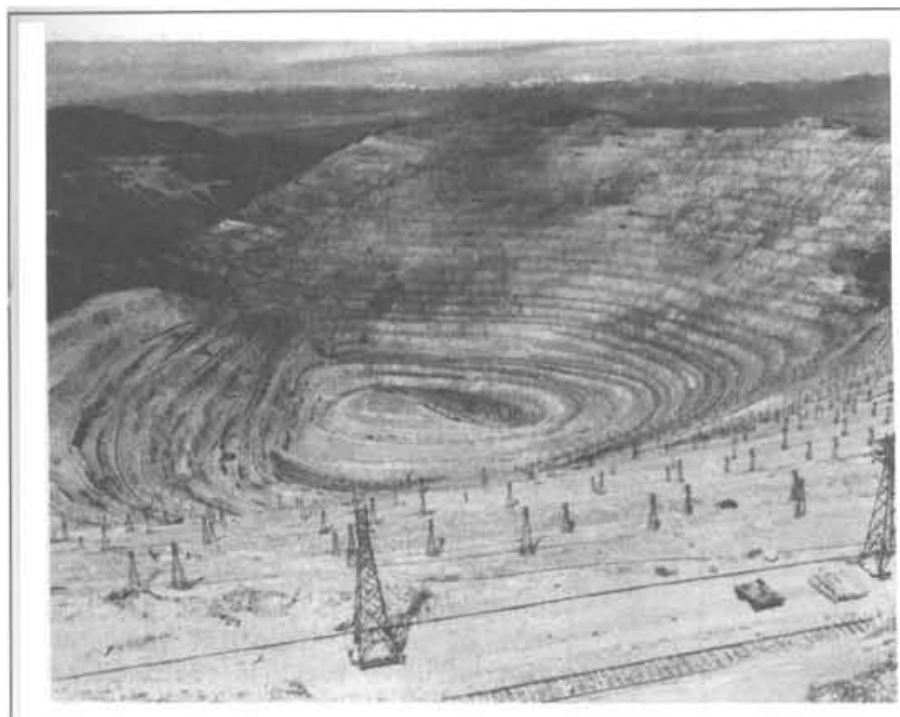

Figure 3: The open pit from which the Kennocott Copper Company mined the porphyry copper deposit at Bingham Canyon, Utah. Porphyry coppers were only recognized as a distinctive type of deposit in this century. Bingham was the first to be recognized and mined when D.C. Jackling and R.C. Gemmell proposed, in 1899, that bulk mining of low-grade ores was possible. Though treated with skepticism, they carried out their idea and by 1907 had a mill working at the rate of 6,000 metric tons per day.

igneous rocks." Those deposits related to igneous eruptions he divided into two further groups, as shown in Table 1. Note that for each class, Lindgren had in mind a characteristic range of temperature and pressure. These, he suggested, controlled the kinds of minerals that formed from the mineralizing solution.

As is often the case, the master understood the lesson better than the disciples. When geologists of a later era accused Lindgren of myopic adherence to magmatic hydrothermalism, they should really have levelled the charge at the disciples, some of whom went to great lengths to prove igneous hydrothermal origins. One famous economic geologist, L.C. Graton of Harvard, obtained his $\mathrm{PhD}$ degree from Cornell for a thesis that argued that the Witwatersrand gold ores are actually classic magmatic hydrothermal deposits. Lindgren disagreed with Graton on the Rand; like Pošepný he realized that geological facts are not always in accord with magmatic hydrothermal origins.

Both Pošepný and Lindgren were firm believers in the notion that an understanding of the genesis of ore bodies is important. But unlike Pošepný, Lindgren made every attempt through his work and argument to understand the larger underlying genetic processes that he felt must account for entire classes of ore deposits. Seek data from individual deposits and understand each thoroughly was his creed, but the goal is to know the underlying, unifying, genetic process for each class of deposits. Pošepný seemed to view deposits as individual entities,

Figure 4: Cartoon cross-section of a hot spring Au-Ag deposit, from B.R. Berger in Cox and Singer (1986). each formed by a unique set of circumstances operating within a continuum of processes. Lindgren viewed deposits as forming through the operation of the same sets of processes repeated again and again in both time and space.

\section{The Modern Scene}

As 1989 and the 28th IGC approach, where is our present thinking regarding mineral deposits? Some of the conclusions now being drawn would sound unfamiliar to Lindgren, but the philosophy guiding the thinking behind the conclusions would be quite familiar. That philosophy is firmly based on the concept that careful study of individual deposits will lead, eventually, both to acceptable classification schemes and an understanding of genetic processes.

Described occurrences of mineralization must now number in the hundreds of thousands in North America. They may reach the millions around the world. As a result, the data pool on which conclusions can be based is enormous. Conformity between deposits, and thus the recognition of deposit classes, is more obvious than it was in 1891, or even 1933. That conformity can now be seen to extend beyond the varieties of minerals present, and such obvious features as grades and tonnage, to features such as the kinds and compositions of the enclosing rocks, tectonic settings, and the geological time range within which a given class of deposits formed.

By inference, conformity of features means conformity of process. Through modern geochemistry, and in particular through the use of both stable and radiogenic isotopes, it is possible to test the inference, and the results are becoming increasingly convincing that conformity of process does produce conformity of features. For example, despite the fact that metamorphism may obscure some of the evidence, it is clear that volcanogenic massive sulphide deposits 2.5 $\mathrm{Ga}$ old formed as a result of exactly the same sets of processes as deposits $2.5 \mathrm{Ma}$ old, and even 2.5 years old. Details of a given process in a certain class of deposits may still elude us, but the scattered signposts consistently point in the same direction. For example, studies of Mississippi Valley-type mineral deposits, regardless of age or geographic location, increasingly point toward the involvement of basinal fluids. There are many unanswered questions, such as the driving forces in the paleoaquifers, thermal budgets, and even the timing of mineralization, but the source of the parental fluids is no longer a mystery.

\section{Mineral Deposit Models}

My own use of the terms Mississippi Valley-type deposit and volcanogenic massive sulphide deposit is one indication of how current thinking is proceeding. Each term carries with it the connotation of a group of features by which the 

four family lines or "logic trees." Those

The logic-tree diagram used by Cox and Singer in, 1986, to define the broad geologic-tectonic environments within which 39 deposit models (classes) and 99 sub-classes are ordered and classified.

GEOLEGICAL ENVIRONMENI

\# of Deposit Models

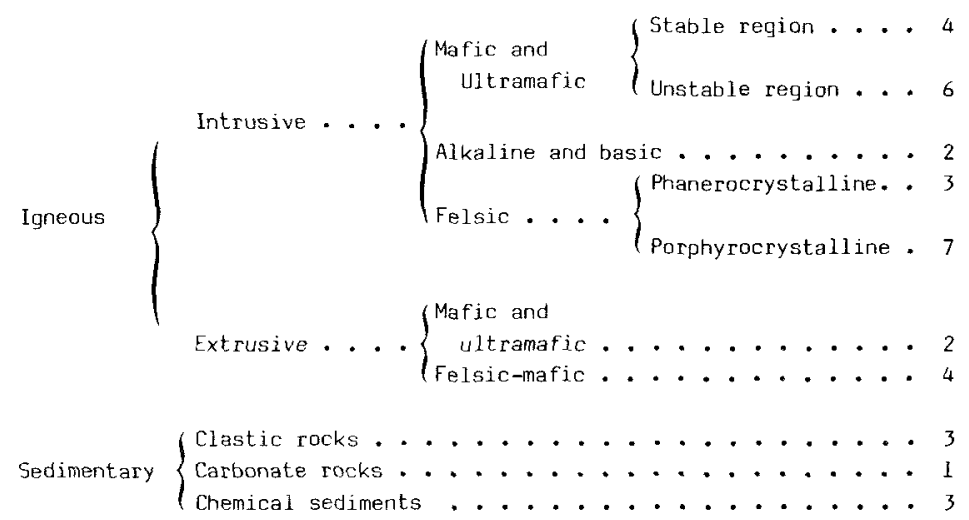

Regional metamorphic

Metavolcanic and

Metamorphic Metapelite

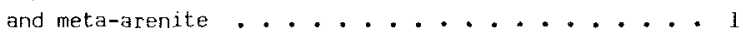

Surficial

family lines are drawn on the basis of geological environmental characters as shown in Table 2. The lines divide into fourteen environmental groups, each of which contains one or more deposit models. Each of the latter describes a class of ore deposit. Models themselves may be divided in two or more sub-classes.

A listing of individual deposits, considering all the models and subclasses, is too large a task for this short paper. Cox and Singer present 39 major deposit models and these are divided into the 99 subclasses, of which they list characteristics for 85. An example of the difference between sub-classes is provided for the two kinds of $\mathrm{Ni}-\mathrm{Cu}$ deposits found in ultramafic intrusive rocks in tectonically unstable regions. One sub-class is in komatiites, the other in dunites. So far as their mineralogy and most other features are concerned, the deposits are similar. Approximately three-quarters of all the recognized sub-classes have representatives in the U.S.A.

Model descriptions and designations are still experimental and are still evolving. Probably they will never be considered complete, but even so they are the best and most concise statements of where our understanding of the mineral deposits of North America is today. I believe that there is a special lesson to be learned from this present situation and in particular from the monumental compilation

deposit type can be characterized. A complete listing of the features found in most examples of a deposit type has come to be called a deposit model. Such a listing is the primary evidence of conformity. Features include anything in the geological environment that can be described, whether small scale or large, such as associated rock-types, mineralogy, ore texture, wall-rock alteration, structural control of mineral deposition, geochemical signatures, age range, and others (Fig. 4).

Two very interesting recent publications summarize current thinking in North America about deposit models (Eckstrand, 984; Cox and Singer, 1986). The data and thinking in these books are influenced by deposits around the world, but the locus is on U.S. and Canadian deposits. Geologists and prospectors have been using such characteristic features in an empirical way for centuries in the hunt for new deposits. What is new today is, to quote Paul Barton in his Preface to Cox and Singer, that "although we must admit that all are incomplete in some degree, models can be put to rigorous tests that screen out many of our heretofore sacred dogmas of mineral formation.

"Examples are legion, but to cite a few; (1) fluid-inclusion studies have shown conclusively that the classic Mississippi valley-type ores cannot have originated from either syngenetic processes or unmodified surface waters; (2) epiihermal base- and precious-metal ores have been proved (by stable-isotope studies) to have formed through the action of meteoric waters constituting fossil geothermal systems; and (3) field and laboratory investigations clearly show that the volcanogenic massive sulphides are the products of syngenetic, submarine, exhalative processes, not epigenetic replacements of sedimentary or volcanic rocks. Economic geology has evolved quietly from an "occult art" to a respectable science as the speculative models have been put to definitive tests." of Cox and Singer and their USGS colleagues. It is simply this: The more we seek variations within and between ore deposits, and the larger our observational pool, the more we will recognize conformity of process. I suspect that at sometime in the future several groups of seemingly unrelated deposits, belonging to quite different classes in today's classification, will be shown to be the products of a single underlying process that operated in different environments.

Pošepny's hunch on this matter was probably correct, and although we still have not proved him right, we are getting closer to doing so. It has already been suggested, for example, that certain volcanogenic massive sulphide deposits may form in parallel with, and as a result of the same underlying genetic system as certain porphyry copper and epithermal gold deposits found in volcanic islands. So too, has it been suggested that the fluid circulation system that forms a sediment-hosted massive lead-zine deposit might also form a Mississippi Valley deposit, and a stratiform barite ore.

\section{A Modern Perspective}

The movement that started in 1891 , and that changed the study of mineral deposits from descriptions of what were then viewed as unique geological accidents, has now largely run its course. Mineral deposits are clearly not geological accidents; they are common, ordinary petrological entities in the crust, they are numerous, and they have formed time and time again. That suggests that ore-forming systems are probably larger and more pervasive than any of us have heretofore thought.

Perhaps, when the IGC returns to the U.S.A. for a fourth visit some forty or fifty years hence, geologists of the time will have answered some of the broader questions concerning the underlying processes. Understanding will come, 
I suspect, through activities including crustal seismic profiling, deep crustal drilling, and refinements of geochemical measurements, especially of stable isotopes. Just as we can look back and see the 5th IGC as the period when economic geology in North America started to become a science, so geologists attending the IGC fifty years ahead may well look back and see the IGC as the time when enlightenment dawned.

B.J. Skinner is Professor of Geology and Geophysies at Yale University (New Haven, CT 06520, U.S.A.) He is currently Chairman of the Scientific Committee of IGCP, and the U.S. National Committee on Geology. Since 1969 he has been Editor of Economic Geology. His research activities are concerned with the genesis of mineral deposits, the geochemistry of ore minerals, and methods of evaluating undiscovered mineral resources.

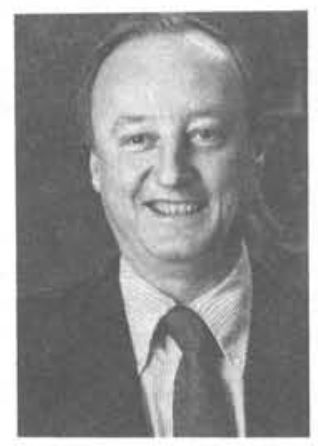

References

Averitt, P., 1945. Quicksilver deposits of the Knoxville district, Napa, Yolo, and Lake Counties, California. California Journal of Mines and Geology, v. 41, no. 2, p. 65-89. Becker, G.F., 1888. Geology of the Quicksilver deposits of the Pacific slope, U.S, Geological Survey, Monograph I 3, 4860.

Cox, D.P. and Singer, D.A. (eds.), 1986. Mineral Deposit Models. U.S. Geological Survey Bulletin $1693,379 \mathrm{p}$.

Eckstrand, O.R. (ed.), 1984. Canadian Mineral Deposit Types: A Geological Synopsis. Geological Survey of Canada, Economic Geology Report 36, 86p.

Gabriel, M. and Pouba, Z., 1986. In Czechoslovakia; Geologist honored for studies of ore genesis. Geotimes, v. 31 , no. 10, p. 19-21.

Lindgren, W., 1900. The gold and silver veins of Silver City, DeLamar and other mining districts in Idaho. U.S. Geological Survey, 20th Annual Report, Part 3, p. 65-256.

Lindgren, W., 1913. Mineral Deposits, Ist ed. MeGraw-Hill Book Co., New York, 884p.

Pošepný, F., 1902. The Genesis of Ore-deposits, 2nd ed. American Institute of Mining Engineers, New York, 806p.

Tingley, J.V. and Berger, B.R., 1985. Lode gold deposits of Round Mountain, Nevada. Nevada Bureau of Mines and Geology, Bulletin 100,62p.

\section{NEW from SWIFT (UK) MODEL "F" H/I AUTOMATIC POINT COUNTER}

is a considerable advance over previous models. Now, with 12 channels - one isolatable from total: Employs microprocessor for compactness, optimum reliability and extra facilities .. such as percentage key and up to $9 x$ interval multiplier: Separate LED displays for channels, and for total plus combined 4-digit preset -- with audible signal.

Point counting is not limited to polarizing microscopes.

Attachments for all well-known microscopes.

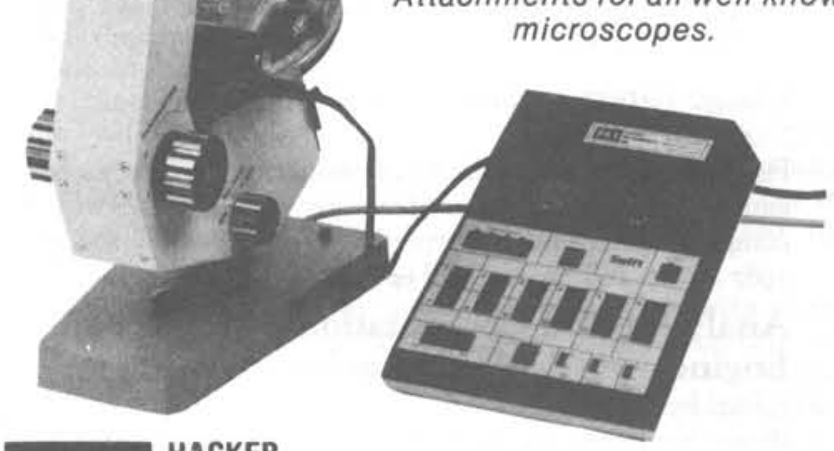

(mon INSTRUMENTS INC.

(201) 226-8450

Global Standards in Stratigraphy

Forecasting Volcanic Eruptions

The Kola Super-Deep Drill Hole

Chinese Loess \& Paleoclimates

Precambrian Paleosols

The Origin of Tethys

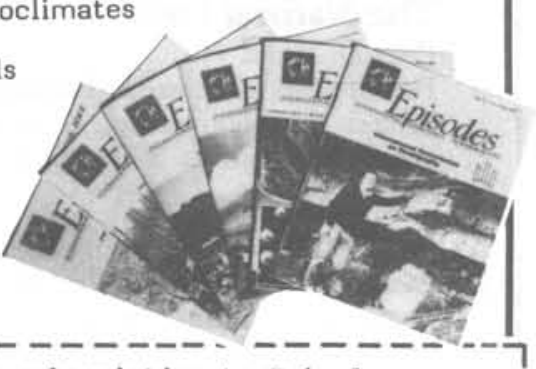

EARTH SCIENTISTS must contend with rapidly advancing knowledge and an ever-growing information base. They must also keep pace with a bewildering diversity of organizations and a wide array of conferences, seminars and workshops.

EPISODES helps solve these problems by covering both scientific and organizational news. Feature articles contributed by leading geoscientists from all parts of the world - review developments at the frontiers of the earth sciences.

EVERY issue includes reports on new developments in international earth science. Other standard features (e.g. book reviews, training courses, coming events) emphasize the resource aspect of the newsmagazine.

IF you are interested in what is going on globally in the geosciences, you should be reading Episodes on a regular basis.

\section{Your Window to the World}


Volcanic Successions: Modern and Ancient

R. A. F. Cas and J. V. Wright

A sedimentological approach is adopted as the main theme in order to facilitate understanding of the broad spectrum of volcanic facies types, the processes responsible for their formation, and their significance in terms of depositional setting. I 987 544pp. HB \$75.00 PB \$39.95

\section{The Young Earth}

An Introduction to Archaean Geology

Euan G. Nisbet

Nisbet's unique and well-written book introduces the Earth scientist to the Archaean, perhaps the most fascinating and scientifically challenging period of Earth history. I987 424pp. HB \$60.00 PB \$34.95

\section{Image Interpretation in Geology}

\section{S. A. Drury}

Firmly based in the traditions of photogeology, Drury's book aims to familiarize new users of remotely sensed images with the complete spectrum of interpretive techniques now available. r 987 256pp. HB \$70.00 PB \$34.95

\section{Analytical and Computational Methods in} Engineering Rock Mechanics

\section{Edited by E. T. Broun}

Brown has drawn together state-of-the-art contributions from leading engineers to provide a number of distinctive methods of special significance in rock mechanics. 1987 288pp. HB $\$ 45.00$

\section{Rheology of the Earth}

Deformation and Flow Processes in Geophysics and Geodynamics

Giorgio Ranalli

Adopting a quantitative approach and developing arguments and ideas from basic principles, this is the first text to deal systematically with the rheology of the Earth. $1987 \quad 384 \mathrm{pp}$.

HB $\$ 60.00$ PB $\$ 34.95$

\section{The Natural History of Nautilus}

Peter D. Ward

Fifteen years of research, including ten of field research, lie behind this illuminating account of the last chambered cephalopod and its 500 million year history. r987 rg2pp. HB $\$ 34.95$

\section{Rates of Evolution}

\section{Edited by K. S. W. Campbell and M. F. Day}

Featuring significant contributions from leading researchers, this book will interest all scientists concerned with evolution and the lively current debate between genetic and molecular studies and paleontology. 1987 226pp. HB \$45.00

\section{Planetary Landscapes}

Revised Paperback Edition

Ronald Greeley

This highly successful and lavishly illustrated book has now been enhanced by the addition of an eight-page chapter on the recent findings of the mission to Uranus. $1987288 p$. PB $\$ 29.95$
Catastrophic Flooding

Edited by Lamy Mayer and David Nash

The proceedings of the 18th Binghamton Geomorphology Symposium examine the causes, dynamics, and effects of catastrophic flooding in fluvial systems. 1987 40opp. HB $\$ 60.00$ The Binghamton Symposia in Geomorphology: 18

\section{Rock Glaciers}

Edited by J. R. Giardino, J. F. Shroder, and J. D. Vitek

Leading researchers in rock glaciers provide insights into movement mechanics, paleotemperatures, classification schemes, applied engineering aspects, and regional characteristics of rock glaciers. 19874 I $6 \mathrm{pp}$. HB $\$ 59.95$

\section{A Practical Approach to Sedimentology}

R. C. Lindholm

As a field-oriented text, this book bridges the gap between books emphasizing the principles and processes of sedimentology and the practical methods used to collect and evaluate sedimentological data. 1987 272pp. HB \$45.00 PB \$ 7.95

\section{Mathematics in Geology}

\section{John Ferguson}

Ferguson's introductory text for geology undergraduates aims to encourage students to become familiar with the mathematical techniques being used in geology today and provides a refresher course for practicing geologists. $1987320 p$ p. HB $\$ 39.95$ PB $\$ 19.95$

\section{Crystal Structures and Cation Sites of the}

\section{Rock-Forming Minerals}

J. R. Smyth and D. L. Bish

The authors present mineral structure and cation site data in a form that will be useful to a broad range of geophysical scientists seeking a deeper understanding of physical properties and element distributions in natural systems. $1987352 \mathrm{pp}$. HB $\$ 50.00$

\section{Bryozoan Evolution}

F. K. McKinney and J. B. Jackson

Abundantly illustrated and based on the well-known research of its authors, this important book will be of interest to all earth and life scientists concerned with paleontology and evolution. I987 320pp. HB \$50.00 Special Topics in Palaeontology: 2

\section{Forthcoming}

\section{Rocks and Landforms}

John Gerrard

In an integration of geomorphology and engineering geology, this book is the first major attempt to examine rock properties scientifically. May I988 288pp. HB $\$ 40.00$ PB $\$ 19.95$

\section{Paleopalynology}

A. Traverse

The study of fossil pollen and spores is completely covered in this text with a laboratory-centered approach. August 1988

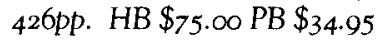

\section{Cathodoluminescence of Geological Materials}

D. J. Marshall

Although cathodoluminescence is now a well-established technique in geological research, this is the first comprehensive book on the subject illustrated in color. June I988 I $28 p p$. HB \$50.00

8 WINCHFSTER PI.ACE • WINCHFSTER, MA 01890 • TOLL. FREE 800-547-8889, In MA and Canada 617-729-0830 